\title{
Violent Conflicts in Africa: Towards a Holistic Understanding
}

\author{
Mark Chingono $^{1 *}$ \\ ${ }^{1}$ Department of Political and Administrative Studies, University of Swaziland, Kwaluseni Campus, \\ Swaziland
}

*Mark Chingono, E-mail: markchingoni@yahoo.com

\begin{abstract}
Violent conflicts in Africa have claimed millions of lives, displaced many more and mortgaged the continent's development. Yet, the study of their causes, dynamics and consequences is far from holistic and unified, but is instead fragmented, contested and divided along disciplines. Part of the problem is that, such complex conflicts are not amenable to mono-causal analysis and rigid theorization, but instead can only be better understood through multidisciplinary analyses of contested historical processes in which local and global forces interact to produce contingent, contradictory and ambiguous trajectories of violent change. This paper attempts to build a more holistic understanding of violent conflicts in Africa that transcends the limits of mono-causal and deterministic models of violence. Critically synthesizing competing perspectives, it highlights some of the many inextricably interlinked local and global causes and escalation factors of violence in Africa.
\end{abstract}

\section{Keywords}

conflict, corruption, democracy, development, economic, ethnicity, governance, holistic, perspectives, theory, violence, religion, resources, state

\section{Introduction}

Violent conflicts are increasingly becoming a major defining feature of Africa's political landscape. Violence is turning the continent into a Hobbesian "state of nature" of "war of each against all" in which life is "short, brutish and nasty" (2016). Violence has claimed the lives of millions, displaced many more, cost more than 150 pounds, and mortgaged the continent's development (Iansa, 2007). The conflicts have also attracted increased but inconclusive research and literature on the continent. As Porto (2002, p. 1) notes, the research has left a "trail of uncertainty, partial clues, contradiction, and continued mystery". Different disciplinary analytical priorities and methodologies have led to "a disturbing lack of integrative knowledge on the subject" (Porto, 2002, p. 1). Research "remains fragmented between disciplinary boundaries, which produce conflicting and often mutually exclusive theories" (Porto, 2002, p. 1). In an endeavor to address this analytical challenge, this paper develops a holistic analytical framework that builds on insights from the contending and mutually exclusive theories of violent conflicts in Africa. 
A broad brush based on secondary research and deductive analysis, the paper advances four interrelated propositions. First, violent conflicts in Africa have many causal and escalation factors, and these include: psychological, political, economic, and social conditions; the nature of the protagonists and key actors; the relations between conflict parties; the conditioning contexts which structure the conflict (economic, ethnic and religious); and external forces. Second, depending on circumstances, any of the many causes of conflict may assume primacy, while other equally important causes may be overlooked, often with serious implications for post-war peace building. Third, underlying the many apparent causes of conflicts in Africa is the undying desire for happiness, a desire which has been frustrated by our inadequate political, economic and social systems. Finally, changes in key actors and of the external environment can lead to a redefinition of the goals of the conflict. In short, the paper argues that individual personalities, social processes, systems and institutions, historical coincidences, and local and global forces have all contributed to shaping the goals, dynamics and consequences of violent conflicts in Africa; the paper's breadth of coverage unavoidably compromises its depth.

\section{Theorizing Violent Conflict in Africa}

Attempts at theorizing African conflicts have "spawned different approaches and frameworks" (Hutchful \& Aning, 2004, p. 197). Distinct theoretical paradigms have emerged, with different emphases and policy recommendations for resolving the conflicts. Broadly these paradigms and generic models include psychological, social, functionalist and formal theories (Miall et al., 1999, p. 66). Paul Wehr (1979) identifies seven competing approaches: conflict is innate in social animals; it is generated by the nature of societies and the way they are structured; it is dysfunctional in social systems and symptom of pathological strain; it is functional in social systems and necessary for social development; it is an inevitable feature of competing state interests in conditions of international anarchy; it is a result of misperception, miscalculation and poor communication; it is a natural process common to all societies. Further attempts to clarify the nature of the issues in conflict have led to the development of "conflict causes" as a new and "most frequently invoked typology" (Porto, 2002, p. 6). According to Singer (cited in Porto, 2002, p. 6), within this typology "all the usual suspects are found: territory, ideology, dynastic legitimacy, religion, language, ethnicity, self-determination, resources, markets, dominance, equality, and, of course, revenge". These schools of thought have apparently irreducible discrepancies on their conceptualization of violent conflict, its causes, dynamics and consequences. Part of the problem is the fact that, truth is often the first casualty of war.

\section{Psychological Theories of Conflict}

In her psychopolitics book, Why War, Rose (1993) stresses the unconscious in our violent cultural and political lives. Personality traits-Machiavellianism, sadism and narcissism - and the subconscious can cause some individuals to be violent. From this psychoanalysis perspective, people with malevolent 
personality traits are "more prone to being duplicitous and self-serving, cold-hearted and lacking in empathy, vain and selfish, and more likely to derive pleasure from other people's pain" (Times of Swaziland, 2015, p. 22). Rebel leaders like Joseph Kony of the Lord's Resistance Army in Uganda and Abu Shakier of Boko Haram in Nigeria, among others, are seen as psychopaths driven by their malevolent personality traits. Thinking out of the psychological box, Freud (1961, pp. 43-44) identifies the inadequacy of "our methods of regulating human relationships in the family, community and the state" as one of the three major sources of unhappiness and conflict: "We cannot see why the systems we have ourselves created should not rather ensure protection and well-being for all of us".

Reflecting psychology's obsession with the individual, Freud (1961, p. 44) advised: "every man must find out for himself in what particular fashion he can be saved. In trying to 'be saved', some have become rebels, criminals, pirates while others have become peace activists or refugees". For Fanon (1968), the Algerian psychologist and freedom fighter, violence against the oppressor can be a liberating and empowering experience. As evidenced by the increasing post-independence disillusionment across Africa, Fanon's celebrated anti-colonial violence did not empower the poor, but instead, and with catastrophic consequences, it entrenched cults of violence into society.

\section{Social Theories of Violence}

Social theories of violence can be broadly divided into processes, structural and functionalist theories. Social process theories depict conflict as a result of social change and interaction between groups, such as the Dinkas and Nuers in South Sudan, Moslems and Christians in Nigeria, Somalia and Mali, seeking to protect their interests by controlling society (Porto, 2002). For Marxists (see Mclellan, 1972), conflict is not only inevitable, but it is the engine behind historical change and development. Conflict is thus "a creative and necessary means of bringing about social change" (Miall, 1999, p. 96). Mazrui's (1995) conception of conflict in Africa as "a retreat from modernity" is therefore ahistorical.

Structuralists posit that violence is: embedded in the social structures of society; a product of the ways in which society is formed and organized and; legitimated by the dominant value system. The childhood psychological and physical violence endured in the family, community, school, and in society tends to produce violent people who know violence as the only strategy of resolving conflict. Rebels racking havoc in Africa can thus be considered products and victims of the violent system. From a functionalist perspective, violence and war perform a necessary function in society. The view that "war is inimical to human progress", most articulated by Nef (1950), has been criticized by Hegel (1967), Hall (1987) and Bayart (1995). While in Europe war helped create the empire and accelerated technological innovation (Hall, 1987), in Africa the social changes it has catalyzed are overshadowed by its destructiveness. 


\section{Causes of Violent Conflict in Africa}

There are many causes of violent conflicts in Africa, and these include, ethnic marginalization, religious differences, access to resources, poor governance and leadership, self-determination and territory. Singer (cited in Potro, 2002, p. 6) identifies "territory, ideology, dynastic legitimacy, religion, language, ethnicity, self-determination, resources, markets, dominance, equality, and revenge" as the key immediate drivers of conflict in Africa. According to Kaldor (1991), such "new wars" are about identity politics and self-determination "in contrast to the geo-political or ideological goals of earlier wars". The growth in such identity politics is due "to the vacuum created by the absence of forward-looking projects and the failure of other sources of political legitimacy, such as socialism or the nation-building rhetoric of first generation post-colonial leaders" (Kaldor, 1991). This paper stresses the failure by the state to satisfy people's desires for decent livelihoods and happiness as the underlying driver of ethnic, religious, ideological and resource conflicts in Africa.

\section{Ethnic and Religious Conflicts}

Beginning in the 1990s ethnic conflict became the "most fashionable term and last resort to explain contemporary social conflicts" (Porto, 2002, p. 6). Examples of violent ethnic conflicts include: the 1980s violent conflict in Matabeleland of Zimbabwe, which, pitted the Shona led government against the Ndebeles, and in which about 20000 people were killed; the Rwanda genocide of 1994 in which about 800000 Tutsis were butchered by Hutu militia in 100 days and; the on-going conflict in South Sudan between the Dinkas and Nuers.

The literature on ethnicity is inconclusive. On the one hand, ethnicity has been depicted as "a primordial or inherited group characteristic" that some consider biologically based (Porto, 2002, p. 7). On the other hand, it is seen as "an instrument", "a tool" contextually "used by individuals, groups, or elites to obtain some larger, typically material end" (Porto, 2002, p. 7). Often "ethnicity is socially constructed, created or de-emphasized by power seeking political elites in historically determined economic and social arrangements" (Sisk, 1996, p. 12). Ethnic identities "wax and wane, contingent on a wide variety of variables, including the capacity and skills of political entrepreneurs who can effectively mobilize groups for collective aims and articulate beliefs about common ancestry and destiny (Sisk, 1996, p. 12). As a basic human need, ethnicity is "fluid, malleable, constructed, and negotiated" (Sisk, 1996, p. 12), and when manipulated by political gladiators, it can spark and fuel violent conflict.

The distinct ethnic dialects and traditions make ethnic identity stronger and more enduring than other collective identities based on class or ideology, and therefore, it is "most likely to provide the basis for political mobilization and conflict when it provides the basis for invidious distinctions among peoples ... that are deliberately maintained through public policy and social practice" (Porto, 2002, p. 8). In and of itself, ethnic identity is innocent, but only becomes a virulent source of conflict when 
economic inequalities are politicized and "ethnicized", and when certain ethnic groups are marginalized or denied access to resources. Invoked only in dealing with real issues of economic inequities and social injustices, ethnicity, like religion, can, at one level, be considered a form of false consciousness. From Biblical times, religion has been both a source of war and peace, and indeed numerous wars have been fought in the name of religion (Chingono, 2014). In north and east Africa a new militant religious ideology, Islamic Jihad, is attracting "youth who are deeply discontented with their governments" to become rebels (cited in Weekend Argus, 2015). Feeding on frustration and disillusionment at poor political and economic governance, religion has engineered the subversion of the state by justifying war in Somalia, Nigeria, Libya, Egypt and Mali.

In Somalia, Al-Shabaab, an Islamist insurgent group which emerged from the ruins of the country's civil war, and which is linked to al-Qaeda, is fighting to establish an Islamist state. Drawing its "support from a conservative Somali population and play[ing] on perceptions of government corruption", Al-Shabaab has "presented itself as a viable alternative to the government in territories it controls, providing citizens with the services and infrastructure the state is unable to offer" (de Villiers, 2015, p. 4). Similarly, in Nigeria, an Islamic militant group, Boko Haram, which means, "western education is forbidden", is engaged in a bloody war against the central government and is trying to form its own state in northern Nigeria under strict interpretation of Islamic law. Dismissed by some Christians as demonic, the group has a membership of about 15000 drawn mainly from the poorest region of the country, and "from uneducated, unemployed and socio-economically disadvantaged Nigerian Northerners who are fed up with corruption, heavy-handed state security forces and neglect of the north" (de Villiers, 2015, p. 3).

In other words, underlying these manifestly religious conflicts are "local grievances as a result of political and socio-economic marginalization and the inequitable distribution of resources in the countries" (de Villiers, 2015, p. 3). Perceived western economic, political and religious domination has given further impetus to anti-West Islamic militancy. As Marx pointed out, religion is therefore not just "an opium of the people", but is also "a cry in a soulless world", a "form of struggle against oppression" and an attempt at setting free a new vision of society (see Mclellan, 1972). In a nutshell, material conditions of poverty and depravation have provided fertile ground for politicizing ethnicity and for religious ideology, which promises a better world of prosperity, to flourish.

\section{Population Explosion and Economic Resource Wars}

Now home to 1.2 billion (up from just 477 million in 1980), Africa's acceleration of annual population growth has given momentum to violent struggles to access and control valuable natural resources, such as minerals, oil, timber, productive pastures and farming land across the continent. Bish (2016, p. 1) warns, "while population growth slows in the rest of the world, it continues to rise in Africa", and with dire consequences. Malthus (1826) had warned of the risks associated the arithmetic progression in 
productivity and geometric progression in population growth. His critics believed progress in science and technology would avert the risks of violent competition for scarce resources associated with over population and overconsumption. As Malthus (1826) feared, and as evidenced by the continent's increasing dependency on food aid, Africa's population growth rates, currently at about 30 million people per year (Bish, 2016), have far outstripped food production increment rates, leading to violent struggles for access to resources, crime and war.

Economic resources, both scarce and abundant, together with other variables, play an important role in the onset and escalation of violent conflict (Lind \& Sturmant, 2002). According to Collier and Hoeffler (2004, p. 7) economic factors are actually "the main drivers of conflict" and "economic agendas are central to the origins and continuance of many civil wars". The use and control of ecological resources as causes of conflicts is motivated by both grievance and greed (Porto, 2002, p. 2). Using an expected-utility theoretical model, with the premise that "rebels will conduct a civil war if the perceived benefits outweigh the costs of rebellion”, Collier and Hoeffler $(2004$, p. 10) conclude that, greed seems more important than grievance: "while the greed model is superior, some elements of the grievance model are likely to add to its explanatory power".

In a chaotic war situation there are a number of possibilities for the greedy to enrich themselves and profit from war. In fact, "various identifiable groups", such as arms dealers, smugglers, illegal miners, poachers, pirates, some businesses and military leaders "do well out of war" (Collier \& Hoeffler, 2004; Keen, 1998; Chingono, 1996). In Liberia, and demonstrating how Africa's wealth has become its curse, faction groups financed the conflict by exploiting natural resources and negotiating "deals with European, American and Asian firms" (Hutchful \& Aning, 2004). Similarly, in Sudan the control of oil and ecological resource fuelled the civil war, while in Nigeria oil sparked localized rebellion against profit seeking multinationals, and led to the death of the Ogoni activist, Ken Sarowiwa. In the DRC too, diamonds and other precious minerals are attracting illegal miners, smugglers, mercenaries, arms dealers and child labourers. According to Amnesty International (eNCA, 2016), multinational companies like Apple, Samsung, Sony, Microsoft, Daimler and Volkswagen, among others, are "indirectly fuelling conflict in the DRC by buying batteries made from cobalt illegally mined in the country" and processed by Huayou Cobalt, a Chinese mineral giant, which employ children as "young as seven years in perilous conditions in the illegal mines".

In some conflicts, although the leaders may be motivated by greedy and profit, rank and file rebels are often motivated by legitimate grievances. In the Mozambique civil war, for example, amnestized rebels claimed that economic deprivation, political marginalization and unrealized independence expectations motivated them to join the MNR rebel movement (Chingono, 1996). Gurr (1993, p. 24) argues: "The greater the deprivation an individual perceives relative to his expectations the greater his discontent; the more widespread and intense is discontent among the members of a society, the more likely and severe is civil strife". Depravation and marginalization breeds disillusionment, which in turn force people to 
adopt violent solutions. In and of itself, however "depravation is no guarantee that groups will pursue their goals using violent behavior" (Porto, 2002, p. 13). In fact, none of Africa's many wars have been started by the poor and marginalized people united in a quest to create a just society. Instead, more often than not, wars are started by the disaffected, and sometimes greedy and power hungry, elite.

In another work, Collier et al. (2006, p. 3) argue that, from an economist's perspective financial viability is the most important cause of conflict: "The economic theory of conflict argues that the motivation of conflict is unimportant; what matters is whether the organization can sustain itself financially". No doubt financial viability is crucial to the success or failure of a rebellion, and indeed without it a rebellion can be stillborn or easily crushed. Nonetheless, to dismiss motivation as unimportant and financial viability as the most important variable in violent conflict seems erroneous. Hypothetically, for instance, in the vast, under-populated and diamond rich Botswana, potential rebels could financially sustain themselves, as in the DRC, through illegal diamond sales, but because there are no serious grievances against the government the country is enjoying relative peace. In other words, financial viability is a necessary condition for sustaining insurgency, but the cause of conflict is to be found in political economy.

Collier et al. (2006, p. 4) further argues that, "economists who have studied rebellions tend to think of them not as the ultimate protest movement, but as the ultimate manifestation of organized crime" in which "'insurgents are indistinguishable from bandits or pirates". True, the need for financially viable has meant that, some "civil wars that appear to have begun with political aims have mutated into conflicts in which short-term economic benefits predominate" (Melaine, 2013, p. 8). Notwithstanding this reality, labeling as "criminals" all those who sacrifice their lives fighting for freedom and independence, for example, the Eritreans who liberated their country from Ethiopia and the South Sudanese from Sudan, is not only to miss the point, but is also arrogant, insensitive and insulting. The rebels' "litany of grievances against the government, for its oppression, unfairness, and perhaps victimization of some part of the population" (Collier et al., 2006, p. 4) is effective propaganda precisely because it resonates with people's daily experiences. Effectively, this economist perspective criminalizes "just wars" and wars of self-determination, wars which are recognized in international law.

Criticizing the economic motives paradigm, Mkandawire (2002) suggests that, the reward for insurgency should be seen not only narrowly in financial or material terms, but also in psychic and spiritual terms. Joseph Kony's Lord Resistance Army in northern Uganda is a typical rebel group that seems not primarily concerned with immediate economic gain, but by grievances against the perceived oppressive and unChristian government.

As Wallerstein (1999, p. 250) aptly puts it: "We have been continuously arrogant in seeking to impose on each other, and with such violence and cruelty, our subjective images of the perfect society". In short, this economist's perspective's embedded practices of "othering", de-legitimizing the "other", and 
"de-valuing" explanations offered by participants-villains and victims alike-constitutes a form of violence which privileges western epistemology over the rest, and as such can only breed hatred and counter-violence.

To sum up, as Porto (2002, p. 14) notes, a "new geography of conflict, a reconfigured cartography in which resource flows rather than political and ideological divisions constitute the major fault lines" has emerged in Africa. Although oftentimes overshadowed by ethnic, religious and weak state variables, economic and ecological variables remain important in virtually all conflicts in Africa. A violent expression of a distributional conflict, resource wars are about the perennial political questions of "who gets what, why and how" of the scarce or abundant resources, questions whose urgency have been amplified by population explosion. Would development be the answer?

\section{Development and Democratization}

Is it a coincidence that Africa, the world's least developed continent, is also one of the most politically unstable? According to Gurr (cited in Porto, 2002, p. 14) "for the last half century at least, societies at low levels of development have suffered much more from societal warfare than prosperous societies". In a similar vein, Collier et al. (1999, p. 7) note: "Civil war is overwhelmingly a phenomenon of low income countries... [and] the higher is per capita income on an internationally comparable measure, the lower is the risk of civil war". They argue that, "higher income per capita reduces the duration of civil war and the probability of its occurrence" Collier et al. (1999, p. 7). Yet, development, like underdevelopment, can also generate violent conflict.

Development, as quantitative changes that lead to qualitative improvements in standards of living, entails new beliefs, values and practices. Oftentimes, these new beliefs, values and practices are resisted by formerly privileged social groups, whose power base is undermined by change. Indeed, development has spurred conflict between traditionalists and modernists, rural dwellers and urbanites, the older and the younger generations, and feminists and patriarchs, with issues like women, children, gay and lesbian rights dividing and unsettling African societies. In a critique of western development discourses, Escobar (1995, back cover blurb) observes that "development policies became mechanisms of control that were just as pervasive and effective as their colonial counterparts". For Escobar (1995), "the struggle against developmentalism is nothing less than a struggle for reclaiming the dignity of cultures that have been turned into a set of experimental subjects, waiting to be sacrificed at the end of a defined set of operations..." To the extent that western forms of development denigrate local cultures, beliefs and practices, they constitute violence, and generate counter violence in the form of wars of self-determination, militant calls for Islamic states and persecution of Christians.

Paradoxically, and through calls for democratization, former slave and colonial masters are forcing freedom on Africans. While to most people democracy is the political vehicle for decent livelihood, equal rights, a reasonable income, access to education and health (Wallerstein, 1991), for African 
dictators, it is a threat to their power and ill-gotten wealth, and thus destabilizing. Dismissing calls for democratization as new forms of colonialism and western domination, some African leaders, for example, in Burundi, Kenya, Rwanda and Uganda have done everything in their power to crush pro-democracy forces, often resulting in violent deaths. In Moslem Africa, and reflecting what Huntington (2011) calls "the clash of civilizations", attempts at democratization are deemed anti-Islam by Islamic Jihadists, and have led to increased anti-state and anti-west militancy. Clearly, as Wallerstein (1999, p. 18) notes: "Everyone speaks of it ... But democratization will not diminish, but add to, the great disorder". The point is, by allowing many voices to be heard, democracy has led to discord and vacillation on controversial policies, thus precipitating conflict and compounding the legitimacy crisis of the state.

\section{The State, Poor Governance and Corruption}

The state in Africa, variously known as a "failed state", "weak state", "neo-patrimonial state" or "kleptocratic state" (Bayart, 1995), and precisely because of its pre-eminent role in either satisfying or frustrating people's needs and desires for happiness, has been at the centre of political instability and violent conflict. Poor governance and leadership, characterized by neopatrimonialism, patronage, personalized rule, incompetency, inefficiency and corruption, have engendered a crisis of legitimacy of the state, which in turn has led to Machiavellian struggles to capture, control, consolidate and use state power against opponents. Hutchful and Aning (2004) observe, "poor governance is the most important single cause of conflict", and poorly governed countries will remain "the primary locale of present and future wars" (Porto, 1999, p. 6). Africa's “'Big Man', the leaders who have dominated the post-colonial era" (Russell, 2000), have completely disregarded the good governance principle of leadership renewal, and consequently threw the continent into violent turmoil. For example, Eduardo dos Santos of Angola and Teodoro Obiang of Equatorial Guinea have been in power since 1979, Museveni of Uganda since 1986, and the late Maummer Gaddafi of Libya since his 1969 coup detat. Museveni, who ended years of murderous rule under dictators, Idi Amin and Milton Obote, and who once said, "leaders who overstayed in power were the root of Africa's problem", has just won a fourth term in an election which was held while his main challenger, Kizza Besigye, was in detention (AFP, 2016, p. 27). Museveni changed the constitution in in 2005 to abolish a two-term limit-Burundi's Pierre Nkurunziza and Rwanda's Paul Kagame have followed suit—and has justified his tenacious hold to power thus: "How can I get out of a banana plantation I have planted and which has started bearing fruits?" (AFP, 2016, p. 27).

When the ruled, frustrated with empty promises, no longer recognize such arrogant and power-hungry rulers as their legitimate representatives, "violent solutions can occur, and the traditional means of using the state to maintain dominant-class hegemony deteriorates" (Gramsci, 1971). As Wallerstein (1999, pp. 17-18) puts it, faith in the rulers had "one enormous political consequence: it was incredibly 
stabilizing. ...Today the world has lost that faith, and having lost it the world has lost its essential stabilizer". Compounding the problems of poor governance and political instability is corruption.

Corruption, which has permeated every sector of society, is not only retarding the continent's development, but is also an important "push factor" for conflict (News24, 2016, p. 26). According to News24 (2016, p. 26), “African leaders are using their defence budgets to buy loyalty and build 'patronage networks', which is driving recruits to" insurgent groups such Boko Haram, al-Queda and al- Shabaab. Russell (2000, p. 12) notes, over the years "Africa has bread more brutal and bloody thirsty tyrants, but no one has so comprehensively pillaged a state" like the "King of Kleptocracy", Mobutu Sese Seko of Zaire (DRC). Boasting to be the second richest man in the world-while his country was becoming a "fourth world" - his "fortune was estimated at between two and five billion pounds" (Russell, 200, p. 18): his ambassador to Japan sold his country's embassy, and was not arrested (Hungwe, 2015). In another "brazen act of kleptocracy", Abacha, Nigeria's military ruler from 1993 until his death in 1998, is suspected to have looted up to $\$ 5$ billion of public funds during his reign (Gaffey, 2016). Nigeria is ranked "136th out of 168 countries in Transparency International's 2015 Corruption Perceptions Index", and $\$ 6.8$ billion in public funds had been stolen by government ministers and bankers between 2006 and 2013 (Gaffey, 2016). Such gross corruption has "undermined states' perceived legitimacy and led to a sense of disillusionment" and violent conflicts across Africa (News24, 2016, p. 26).

In short, with a few exceptions, and from colonialism to the present, African people have been under gangster and thug rule. At independence, White colonial racialists were replaced by Black pseudo-revolutionaries who, sooner than later, became the new greedy oppressors of their people. In a classic replay of Orwell's (2014), Animal Farm, erstwhile freedom fighters, like mercenaries, are violently suppressing their people's freedoms and demanding a larger share of the dwindling "national cake". Such poor leadership, mis-governance and corruption have not only held back development but have also fuelled conflicts, as poor governance and corruption increase the risks of conflict and, as happened in the DRC, Somalia, Sierra Leone, Liberia and Libya, "whenever a dictatorship collapses there is a civil war" (VOA, 2015, p. 2). Ominously, and presumably to get away with genocide and mass murder, some African leaders are contemplating leaving the International Criminal Court: a glimmer of hope is offered by the Senegalese president, who offered to reduce his term as president, and the new Tanzanian president, John Magufuli, who has "shaken Tanzania to its core as [he] went in search of" corrupt public officials (Warunga, 2016, p. 21), and who has substantially cut down government expenditure. The African state's legitimacy crisis and violence can be traced back to the colonial era. 


\section{Colonial and Global Roots of Africa's Conflicts}

The political economy of Africa, and its current susceptibility to violent conflict, was defined by the economic and political interests of European powers under colonialism. As Azar (1990, pp. 10-12) points out, "contemporary war can be understood better if we explore the birth of states and how they have come to be governed". Established during colonialism to protect the parochial interests of a white settler minority which controlled the economy (mining, industry and agriculture), the state was never seen as legitimate by the colonized. First, colonialism was a imposed through violence, and not surprisingly it generated cults of counter violence in the form of violent liberation wars in, for example, Angola, Algeria, Mozambique, Namibia and Zimbabwe among others. Contemporary cults of violence and counter-violence in some African countries are therefore a continuation of the violence of colonialism.

Second, inherited intact at independence, the post-colonial state has retained its colonial trappings, and has at best been unable to satisfy the needs of the majority, and at worst has frustrated them, thus catalyzing the degeneration of politics into warfare. As a "capstone state" imposed atop local communities from above (Hall, 1987) or a "balloon suspended in mid-air" lacking organic roots into society (Hyden, 1986), the post-colonial state cannot be expected to promote popular happiness. Established to protect the parochial interests of white settler minorities, the post-colonial state, in its present form, is a blunt tool for the task of satisfying the needs of a culturally and ethnically diverse majority. The wars in Somalia, Nigeria and Mali are thus partly a manifestation of inappropriateness and inadequacies of the post-colonial state.

Third, arbitrary colonial boundaries, which separated some ethnic groups into different countries while forcing other different ethnic groups into one country, have been a major source of ethnic conflicts and even genocide. For example, the Hutus and Tutsis of Rwanda and the Shona and Ndebele of Zimbabwe had lived as neighbouring kingdoms in the pre-colonial period, only to be forced into one nation by colonialism. As a result both countries have experienced ethnic violence and genocide; in Zimbabwe a Matabeleland based group is seeking autonomy and statehood of the Mthakwazi (Matabele) land. Border conflicts, such the one between Botswana and Namibia over Sedudu Islands, and secessionist wars, such as the one that led to the break-up of Eritrea from Ethiopia and South Sudan from Sudan, are all obvious consequences of arbitrary colonial boundaries.

Forth, and with even far reaching ramifications, colonialism entrenched dependency of African states on their former colonial masters, and completely shaking off the joke of colonial dependency is proving a difficult task. More than half a century after it was formed as the Organization of the African Union, the African Union (AU) is still struggling to be financially independent. As the AU Commission chairperson, Nkosana Dlamini-Zuma lamented, "the continent's heavy dependency on funding from the West"-Canada, Sweden, Germany, the Netherlands, Spain, Turkey, the World Bank and the European Union - poses a "risk of those countries dictating the AU's activities" (Times of Swaziland, 
2016, p. 4, p. 13). The post-colonial state's capacity to deliver and satisfy communal interest is limited by its dependency on the west, the inequitable international system and a "rigid or fragile authority structure which prevents the [it] from responding to, and meeting, the needs of various constituents" (cited in Miall, 1999, p. 74).

Finally, in order to protect their national interests, former colonial powers have continued to meddle with Africa's internal politics, supporting some groups while opposing others and thereby contributing to violent conflict. Al Jazeera's (2014) French African Connection documentary shows the extent to which the French have gone in trying to ensure that African rulers in its former colonies defend French interests. African leaders opposed to Western interests, like the late captain Sankara of Burkina Faso, Patrice Lumumba of Congo (now DRC), and Nkwame Nkrumah of Ghana were deposed through Western complicity, and African states that try to resist western domination, such as Zimbabwe, are often demonized and punished with sanctions.

Dominated by global forces, many of Africa's conflicts have external roots, while others are residues from Cold War politics. As Reno (1999, p. 45) argues, warlord politics in Africa are partly an inevitable consequence of "the end of the Cold war", which "shifted the distribution of opportunities available to African rulers, whose old strengths and vulnerabilities were altered as they responded to these changing external conditions". In a similar vein Azar (1990, p. 155) notes: "Many conflicts currently active in the underdeveloped part of the world are characterized by a blurred demarcation between internal and external sources and actors". During the Cold War the superpowers, in their struggle for hegemony and expansion of "spheres of influence", supported client movements and states as proxies and surrogates. For example, in Angola and Mozambique's civil wars the West supported rebels while the former Soviet Union supported the socialist governments respectively.

The withdrawal of support at the end of the Cold War not only led to the end of the proxy wars, but it also created a power vacuum whose inevitable results include, "the spread of violence and the emergence of disparate groups, ostensibly fighting in the name of ideology, religion or ethnicity, but seeking to finance their operations through local taxation, plunder and pillage" (cited in Porto, 2002, p. 4). Although the Cold War is over, powerful nations still seek to expand their influence in Africa. In an endeavor to counterbalance the West Russia, for example, is expanding its influence in Africa through arms export, which fuels conflict: "Russia is pursuing costly state oil and platinum projects in Africa... hoping they will bolster sales, including of arms..." (Zimbabwe Situation, 2015). Not to be outdone, China is effectively colonizing the continent through unfair economic deals, such as mineral concessions.

Even more pernicious, international institutions, such as the International Monetary Fund, the World and the United Nations Security Council, among others, are not only controlled by powerful states, but also operate in ways that marginalize and impoverish African states. The UN Security Council is not only the most powerful institution in the world but, and as embodied in the veto power principle, is also 
the most anti-democratic. Veto power is meant to protect the interests of the five powerful permanent states of the US, UK, France, Russia and China, often at the expense of weak African states. Calls for reform of the UN Security Council, and in particular to include Africa, Asia, Latin America and other European countries as permanent members of the Security Council, have hitherto yielded no tangible results. The point is, Africa's marginality in the global power structure, and as evidenced by the UN's half-hearted response to the Rwanda genocide of 1994, increases risks and impacts of violent conflict. The international division of labour, which was established during the colonial era, encourages African countries to export raw materials and import manufactured goods. Since raw materials are more susceptible to deteriorating terms of trade, this model of development entrenches African dependency on technologically advanced countries, leads to increasing trade imbalances, balance of payments deficits and debt, all of which undermine development and the continent's capacity to deal with or avert violent conflict.

An even more invidious global source of violent conflict in Africa is the attempt by the West to impose supposed universal truths and value systems on the continent. Western truths, argues Wallerstein (1999, p. 155) "are not universal truths and if there exist universal truths, they are complex, contradictory and plural". Far from being universal truths, supposed Western truths may, especially in colonial and post-colonial contexts, constitute a form of violence against the other. As Wallerstein (1999, p. 155) notes, Western arrogance and a racial superiority complex, has been "humanity's greatest self-imposed limitation" and a pernicious source of violence in Africa in particular, and the Third World in general. In Mali, Nigeria and Somalia, for example, the Islamist insurgents are violently rejecting these "western truths", values of democracy and gender equality, which they deem anti-Islamic, and they instead seek to establish their own Islamic value systems; imperialism is not dead, but is alive and breeding anti-west militancy in Africa in particular, and the Third World in general. In short, colonialism and globalization, by entrenching dependency and domination by global forces, have contributed to the continent's susceptibility to violent conflict. To recapitulate, wars in Africa are caused and fuelled by many interrelated local and global factors that mutually reinforce each other. As the case of Mozambican civil war discussed below clearly illustrates, in any one conflict, there is often more than one causal and escalation factors.

\section{Mozambique's Civil War}

Mozambique's civil war, 1977-1992, which by 1990 had claimed the lives of about one million, displaced many more, and cost the country US\$ 18 billion in economic losses (Hanlon, 1993), which was equivalent to four times the 1988 GDP (Saferworld, 1994), is a typical case which shows the multiplicity of causal factors in a single conflict. In the vicious conflict, personal psychology, social structural and systemic factors all contributed immensely to generating and fuelling the war. Distinct and contending perspectives on the causes of war can be identified. 
First, the individual personalities of both the founding leader of the MNR (Renamo in Portuguese), Andre Matada Matsangaisse (the movement is also known as Matsangaisse by the locals) and that of Mozambique's first president, Samora Machel, played important roles in fermenting the violent conflict. As the story goes, Matsangaise was a former Frelimo cadre who was disenchanted by the punishment meted out to him for some indiscipline. After release from detention barracks, Matsangisse, being of an arrogant and aggressive disposition, was dying for revenge, and when the Rhodesians approached him his dreams came true (Vines, 1991). Equally responsible for fuelling the conflict was independent Mozambique's first president Samora Machel. A nurse turned guerrilla leader, Machel was dictatorial and militaristic and was not ready to compromise or negotiate with the rebels, who he contemptuously dismissed as surrogates of apartheid South Africa. The war ended when Chissano, the "quiet diplomat", took over as president in 1986 after Machel's death in a suspicious plane crash. Chissano bargained and compromised with the MNR during a prolonged peace process which resulted in the Rome Ceasefire Agreement of 1992.

Second, and as is always the case, both the belligerents claimed to be fighting for the noble ideals of freedom, justice, and peace; fighting for peace is a contradiction in terms. For example, Hoile (1989) argues that the rebellion was "bona fide" struggle for democracy and freedom by an oppressed people under communist ideology. Third, others like Vines (1991) stress the colonial roots of the conflict. Vines (1991) argue that the MNR, which was funded by some Portuguese businessmen, was born as a Rhodesian counter-insurgency fifth column, meant to counter the Frelimo government's support of Zimbabweans freedom fighters based in Mozambique.

Forth, and focusing at a later stage of the conflict, when the MNR had been inherited by SA at Zimbabwe's independence in 1980, Hanlon (1993) stresses apartheid South Africa's "total strategy" of destabilizing the frontline states, especially those that haboured ANC freedom fighters, as the main cause of the conflict. Fifth, and related, the Cold War, as manifested in the ideological conflict between Eastern block-backed Frelimo's socialist government and western-backed Renamo rebels, fuelled the conflict. Thus both Frelimo and Renamo were proxies and surrogates of the communist and western blocs, respectively, which provided them with material and ideological support. Not surprisingly, the end of Cold War led to the end of the civil war.

Sixth, ethnicity was a latent causal and escalation factor in the conflict. Reflecting the ethnic divisions, the ruling Frelimo is dominated by Southerners while the rebel Renamo by Ndaus from the central region. Indeed, some people in the central and north provinces complained that, because of the ethnic bias of the Frelimo government, the economic resources of the country are used to develop only the south and areas around the capital Maputo (Chingono, 1996). Seventh, Frelimo's attempt at suppressing both Christian and traditional religions, which it deemed archaic and primitive, forced peasants to turn their backs against the Frelimo government and support the rebel cause (Geffray, 1990). For the peasantry, steeped in tradition, superstition, spiritualism and ancestor veneration, Frelimo's socialist 
ideology which condemned religious beliefs and practices as archaic, and "obscuntarist" was threatening. In protest against suppression of their traditions and religious beliefs, many a peasantry, especially from the central regions of Manica and Beira provinces, voluntarily joined the ranks of the rebels (Geffray, 1990). Religion not only fuelled and legitimated war, but it also helped people deal with the tensions that arise from violent social change by providing the means for negotiating the personal, social and political conditions they experience.

Eighth, and as evidenced by the current demands by RENAMO to violently get autonomy for six provinces of the central and northern regions, the desire for territorial control and self-determination. Critics have dismissed these demands as naked greed for power. In fact, and finally, and as rational choice theorists (Keen, 2004) stress, some corrupt and greed groups-military commanders, arms producers, illegal dealers - fuelled the war because they profiteered from it.

Ninth, changes in the key actors and in the internal and external environments led to changes in the goals and dynamics of the conflict. For example, the death of Machel and the end of the Cold War, contributed to the end of the civil war. After the collapse of the eastern bloc, Mozambique, a former Portuguese colony, not only joined the west but even became a member of the Commonwealth; in politics and international relations there are no permanent friends. Finally, the importance of certain factors varied with the stage of the conflict. For example, at the beginning of the Mozambican civil war, ideology and Cold War politics were the major driving factors of the conflict. Today, with the former socialist Frelimo government having embraced capitalism and the Cold War over, ethnicity-which was underplayed during the civil war-is now the major source of tensions.

In short, personalities, ideology, East-West rivalry, regional geopolitics, ethnicity, religion, economic resources and/or marginalization all contributed to fuelling the conflict (Chingono, 1996). Consequently, as Mozambique's experiences suggests, none of the contending perspectives on the violent conflict in Africa is completely correct or entirely wrong, but instead each present a partial picture of the far more complex reality of violent conflict. As Miall, H et al. (1999, p. 66) observes, no single "all-encompassing explanation will be adequate for conflicts of different types with different starting points... that have different histories and cultures and are at different stages of economic and political development". Therefore the challenge is to transcend the inherent limits of mono-causal and ahistorical analysis by developing a more holistic and multi-disciplinary approach based on a critical synthesis of the contending theories.

\section{Towards a Holistic Theory of Conflict in Africa}

A multiplicity of multilayered and interrelated local and global causal and escalation factors coalesce to generate violent conflicts in Africa. The most important and recurrent factors in causing conflict include, political governance, social structures and processes, individual personalities, ethnicity; religion, ideology, economic motives (both greedy and grievances), the colonial legacy, the 
international capitalist system and global power politics. The importance of these factors varies in different conflicts and contexts, in different phases of a conflict, and some factors are overshadowed by others during conflict.

For instance, in the DRC access to mineral resources seems the major catalyst of conflict, but in Mali, Nigeria and Somalia it is religious ideology, while in Burundi, CAR and Kenya it is poor governance and democratization. In most conflicts there are often multiple and multilayered causal and escalation factors that coalesce to create conditions for violent conflict. For example, in the North and South Sudan conflict, self-determination, territory, religion (Christian south versus Moslem north) and economic resources (sharing of oil revenue) all contributed to the conflict. As in Mozambique, the influence of certain factors varies with the phases of the conflict, and changes in both the key actors and/or the external environment influence the dynamics of the conflict.

Invariably, and partly because of both governments and rebels' propaganda campaign, some of the important causal and escalation factors are underplayed during war, only to destabilize the post cease fire peace. In Libya, Nigeria, Mali and Somalia, for example, Islamic fundamentalism is portrayed as the major cause of conflict, yet such religious militancy is feeding on poverty, economic marginalization and disillusionment. As de Villiers (2015, p. 3) observes, underlying these manifestly religious conflicts are "local grievances as a result of political and socio-economic marginalization and the inequitable distribution of resources" in these countries. Resources, ideologies, religions and other factors identified above as causes of conflict are essential means to happiness, however conceived.

The overarching cause of violence in Africa, which underlies the apparent causes, is therefore the desire for the good life and happiness. State failure to satisfy this undying desire for happiness has fuelled violent conflict in Africa. As Freud (1961) aptly observed, the inadequacies of our methods for regulating human relationships at the family, community, national and international levels are the major source of unhappiness and conflict. This failure, especially in economic and political governance, has increased the gap between what people want and what they get, expectations and gratifications, and has become the main driver for violent conflict. Through its monopoly of power, the state can satisfy or frustrate certain basic communal needs, thus preventing or promoting conflict (Azar, 1990, pp 10-12). Yet, as Gramsci (1978, p. 83) pointed out, when, and for whatever reason, the state experiences a crisis of legitimacy and the hegemony of the governing class deteriorates, violent solutions can occur. Compounding the legitimacy crisis of the state and hence fuelling violence is globalization, which has accelerated social division, fragmentation and polarization.

In short, as Jabri (1996, p. 8) suggests:

War is (a) a multicausal phenomenon, where different causal sequences may apply to different conflict situations, and (b) a result of decision-making paths which, far from suggesting rationality... point to the view that rationality is bounded by institutional roles and established norms which impact upon the informational and analytic loops which actors may go through prior to the onset of war. 
Tilly (2007, p. 5) observes, collective violence erupts as a result of a "confluence of shared interests"-between local groups and global actors - that must be "organized, mobilized and resourced" in the "continuous power struggle between those who have decision-making powers, and those who have not". To identify the "confluence of shared interests", the historical processes and choices leading to, and presented by, violent conflict, a holistic and multi-disciplinary analytical framework that integrates insights from different disciplines is needed.

\section{Summary and Conclusion}

The simultaneous ubiquity and uniqueness of war is perhaps the most glaring feature which comes out glaringly clear in African conflicts. Attempts at understanding the seemingly senseless wars have led to the emergence of competing theoretical accounts of war, with different scholars focusing on, and emphasizing, different causes and dimensions of conflict. Incompatible as they are, there is an element of truth in each of these perspectives, for people go to war for a multiplicity of reasons.

As shown, political violence in Africa has many inextricably interlinked, local and global, causal and escalation, factors, some more or less important than others. The personalities of the protagonists, the relations between conflict parties, economic, ethnic and religious conditions, and external forces have all contributed to shaping conflict goals and dynamics. Underlying these apparent causes of conflict is the desire for happiness. Therefore, to paraphrase Clausewitz (1971), for the pleasure seeking animal, man, war is a pursuit of happiness by other means. By its very nature, war, its goals and dynamics, are neither amenable to the certitude of rational calculation nor to mono-causal analysis.

Thus, to get a big picture of such complex wars, a holistic and multi-disciplinary approach that transcends the limits of the "intellectual silos" paradigm and that integrates the competing theoretical perspectives is necessary. A holistic approach is also necessary because the globe is "home to different cosmologies with different diverse knowledge systems and, each of these may have different ways of knowing and [justifying war], often these are indeed constituted at different realities" (CODESRIA, 2015 , p. 1). Only through a holistic analytical framework that stresses the complex interconnections between the various, local and global, multiple and multilayered, apparent and latentcauses of conflict can we hope to make sense of the chaos.

\section{References}

AFP. (2016). Uganda's Museveni Looks to a Fourth Decade in Power. Swazi Observer, 17 February, 27. Mbabane.

Al Jazeera. (2014). The French Africa Connection: France's Thirst for Energy, 3 September.

Azar, E. (1990). The Management of Protracted Social Conflict: Theory and Cases. Aldershot, Dartmouth.

Bayart, J. F. (1995). The State in Africa: The Politics of the Belly. London, Longman. 
Bish, J. J. (2016). Population Growth in Africa: Grasping the Scale of the Challenge. The Guardian, 11 January.

Chingono, M. (1996). The State, Violence and Development: The Political Economy of War in Mozambique. Aldershot, Avebury.

Chingono, M. (2014). Religion, War and Politics: Reflections on Mozambique's Civil War (1977-1992). The Journal of African Political Science and International Relations, 8(2).

Clausewitz, C. V. (1971). On War. London, Penguin.

CODESRIA. (2015). Call for Proposals: WISC-IRIIS Exploratory Workshop. Retrieved from http//www.codesria.org/spip.php?article2476\&lang=en

Collier, P. et al. (1999). On the Duration of Civil War. Mimeo, DECRG, World Bank.

Collier, P. et al. (2006). Beyond Greed and Grievance: Feasibility and Civil War. Department of Economics, University of Oxford, Oxford.

Collier, P., \& Hoeffler, A. (2004). Greed and Grievance in Civil War. Oxford Economic Papers 56 (pp. 563-595). Oxford University.

De Villiers, S. (2015). Factsheet: Conflict-related deaths in sub-Saharan Africa. Retrieved from http://www.africacheck.org/factsheets/conflict-related-deaths-in-sub-saharan-africa/ 24 September

Enca. (2016). Is your cellphone powered by child labour? Swazi Observer, 21 January, 23. Mbabane.

Escobar, A. (1995). Encountering Development: The Making and Unmaking of the Third World. Princeton, Princeton University Press.

Fanon, F. (1968). The Wretched of the Earth: The Handbook for the Black revolutionary that is Changing the Shape of the World. New York, Grove Press.

Freud, S. (1961). Civilization and its Discontents. New York, W.W. Norton.

Gaffey, C. (2016). Nigeria and Switzerland Agree Return of \$321 Million in Stolen Abacha Funds. Newsweek, 9 March.

Geffrary, C. (1990). La Cause des Armes au Mozambique: Anthropologie d'unegueere civile. Paris, Karthala.

Gramsci, A. (1978). Selection from Political Writings, 1921-1926. London, Lawrence and Wishart.

Gurr, T. (1993). Minorities at Risk: A Global View of Ethnopolitical Conflict. Washington DC, United States Institute of Peace.

Hall, J. A. (1987). War and the Rise of the West. In C. Creighton, \& M. Shaw (Eds.), The Sociology of War and Peace. London, Macmillan.

Hanlon, J. (1993). Mozambique: Who Calls the Shorts? London, James Currey.

Hegel, F. (1967). Phenomenology and the Philosophy of Right. Oxford, Oxford University Press.

Hobbes, T. (2016). Leviathan or The Matter Forme and Power of a Commonwealth Ecclesiastical and Civil.Adelaide,ebooks@ Adelaide.

Hoile, D. (1989). Mozambique: A Nation in Crisis. London, Claeridge. 
Hungwe, B. (2015). Cannibalism Consumes Gweru. Zimbabwe Situation. Retrieved from http://www.zimbabwesituation.com/news/zimsit-w-cannibalisn-consumes-gweru-the

Hutchful, E., \& Aning, K. (2004). The Political Economy of Conflict. In A. Adebajo, \& I. Rashid (Eds.), West Africa's Security Challenges: Building Peace in a Troubled Region. London, Lynne Rienner.

Hyden, G. (1986). No Short Cuts to Progress. London, Heinmann.

Iansa, O. S. (2007). Africa's Missing Billions: International Arms Flows and the Cost of Conflict. Briefing Paper, London, Oxfam.

Jabri, V. (1996). Discourses on Violence: Conflict Analysis Reconsidered. Manchester, Manchester University Press.

Kaldor, M. (1991). The Imaginary War: Understanding the East-West Conflict. London, Blackwell.

Keen, D. (1998). The Economic Function of War in Civil Wars. Adelphi Paper 320, London, International Institute for Strategic Studies.

Lind, J., \& Sturman, K. (Eds.). (2002). Scarcity and Surfeit: The Ecology of Africa's Conflicts. Pretoria, Institute of Security Studies.

Malthus, T. R. (n.d.). An Essay on the Principle of Population. Retrieved from http://www.econlib.org/library/Malthus/maIplong.html

Mazrui, A. A. (1995). Conflict as Retreat from Modernity: A Comparative Overview. In O. Furley (Ed.), Conflict in Africa. London, Tauris Academic Studies.

McLellan, D. (1972). Karl Marx: His Life and Thought. London, Penguin.

Melanie, F. (2013). Conflict Resolution: Peace Implementation in New Wars. Berlin, Flowers Publication.

Miall, H. et al. (1999). Contemporary Conflict Resolution: The Prevention, Management and Transformation of Deadly Conflicts. Cambridge, Polity Press.

Mkandawire, T. (2002). The Terrible Toll of Post-Colonial Rebel Movements. Africa: Toward an Explanation of the Violence Against the Peasantry, JMAS, 40(2), 181-215.

Nef, J. (1950). War and Human Progress. Cambridge, Harvard University Press.

News24. (2015). Fours Years On, Gaddaffi Legacy Haunts Libya. Swazi Observer, 31 October. Mbabane.

News24. (2016). African Corruption 'Pushing' Recruits to Insurgents. Swazi Observer, 21 January, 26. Mbabane.

Orwell, G. (2014). Animal Farm. Adelaide, ebooks@ Adelaide.

Porto, J. G. (2002). Contemporary Conflict Analysis in Perspective. In J. Lind, \& K. Sturman (Eds.), Scarcity and Surfeit: The Ecology of Africa's Conflicts. Pretoria, Institute of Security Studies.

Reno, W. (2000). Warlord Politics and African States. London, Lynne Reinner Publishers.

Rose, J. (1993). Why War? Cambridge, Blackwell. 
Russell, A. (2000). Big Man, Little People: Encounters in Africa. London, Pan Books.

Saferworld, (1994). The Cost of Conflict. London, MaMillan.

Sisk, D. T. (1996). Power Sharing and Ethnic Mediation in Ethnic Conflicts. Washington DC, USIP and Carnegie Commission on Preventing Deadly Conflict.

Tilly, C. (2007). Democracy. Cambridge, Cambridge University Press.

Times of Swaziland. (2015). You Could be a Psychopath If You Enjoy Coffee, Gin. Times of Swaziland, 12 October, 22. Mbabane.

Times of Swaziland. (2016). Comment. Times of Swaziland, 13 February, 4. Mbabane.

Vines, A. (1991). Renamo Terrorism in Mozambique. London, James Currey.

VOA. (2015). Top Academic Says Zanu PF Factionalism Recipe for Civil War in Zimbabwe. Zimbabwe Situation. Retrieved from http://www.zimbabwesituation.com/news/zimsit-m-topacademic-says-zanu-pf-factio

Wallerstein, I. (1999). The End of the World as we Know it: Social Science for the Twenty-First Century. London, University of Minnesota Press.

Warungu, J. (2016). Five Gifts for Five African Presidents. Times of Swaziland, 21 February, 19.

Weekend Argus. (2015). Islamists Target the Discontented. Swazi Observer, 21 September, Mbabane.

Wehr, P. (1979). Conflict Regulation. London, Westview.

Zimbabwe Situation. (2015). Russia Turns to Africa to Boost Arms Sales. Retrieved from http://www.zimbabwesituation.com/news/zimsit_w_russia-turns-to-africa-to-boost-arms 